\title{
Nutritional rickets in 2 very low birthweight infants with chronic lung disease
}

\author{
ALBERT E CHUDLEY, DAVID R BROWN, IAN R HOLZMAN, AND KOOK SANG OH \\ University of Pittsburgh School of Medicine, Department of Pediatrics, Division of Neonatology, Magee- \\ Womens Hospital, and the Department of Pediatric Radiology, Children's Hospital of Pittsburgh, Pennsylvania, \\ USA
}

SUMmaRY Two very low birthweight infants with rickets are described; one had a low serum 25-hydroxy-vitamin D3 concentration. Similarities in their clinical courses included low birthweights, low calcium intakes, uncertain vitamin D intakes, and chronic administration of frusemide and sodium bicarbonate-all potential aetiological factors in the development of bone undermineralisation. Both infants had a resolution of their chronic lung disease before their treatment for rickets. This experience has led us to the more cautious use of frusemide and sodium bicarbonate in infants at risk for rickets, and shows the need to ensure daily vitamin D supplements.

Very low birthweight infants are known to be at risk of developing vitamin $D$ deficiency rickets. ${ }^{1-3}$ In this report we describe 2 chronically ill infants of very low birthweights who developed rickets, and discuss the factors in their clinical courses that may be important in the development of their bone disease.

\section{Case reports}

Case 1. This $960-\mathrm{g}$ girl was born at 27 weeks' gestation. The Apgar scores were 4 at one minute and 3 at five minutes. She required mechanical ventilation from days 2 to 18 of life to treat respiratory distress syndrome. She needed increased ambient oxygen until 100 days of age and the diagnosis of bronchopulmonary dysplasia was confirmed on $x$-rays.

Formula feedings were supplemented with a parenteral amino-acid infusion on days 5 to 12 . Routine multivitamin supplement $(400 \mathrm{IU} / \mathrm{ml}$

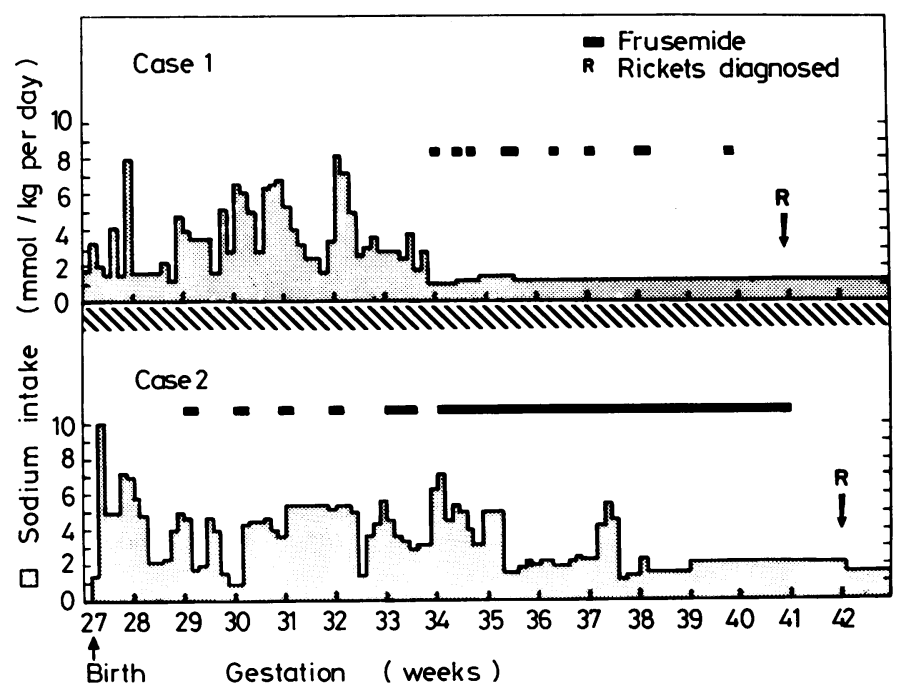

687
Fig. 1 Relation of sodium intake and frusemide administration to the time of diagnosis of rickets in Cases 1 and 2. 


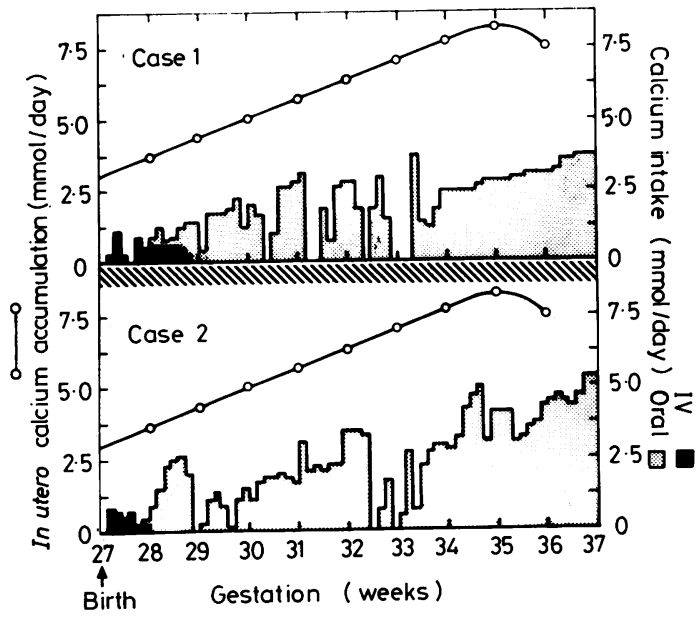

Fig. 2 Comparison of expected in utero calcium accumulation 14 and actual calcium intake in the first 10 weeks of life before the diagnosis of rickets in Cases 1 and 2.

Conversion: SI to traditional units - calcium: $1 \mathrm{mmol} / 1 \approx 4 \mathrm{mg} / 100 \mathrm{ml}$.

vitamin D) was ordered, but its daily administration was not recorded in her medical record. Feeds were often interrupted during the first 4 weeks of life because of respiratory problems. A mixed acidosis was treated with oral sodium bicarbonate (1-3 mmol per day) for the first 50 days.

From 4 to 10 weeks of age oedema was present. In the absence of any other reason for the oedema, excessive sodium intake was suspected (Fig. 1), and at age 46 days the infant's formula was changed to a low-sodium formula which also contained threequarters as much calcium as the initial formula
(Fig. 2). Intermittent intramuscular doses of frusemide (1-2 $\mathrm{mg} / \mathrm{kg}$ ) were given for signs of pulmonary and peripheral oedema (Fig. 1). The oedema resolved by day 110 of life and treatment with frusemide was stopped.

Clinical signs of rickets were noted at day 100 and the diagnosis was confirmed by $x$-rays (Fig. 3). Serum calcium (Ca) was $2 \cdot 25 \mathrm{mmol} / 1(9 \cdot 0 \mathrm{mg} / 100$ $\mathrm{ml}$ ), inorganic phosphorus (P) $0.94 \mathrm{mmol} / \mathrm{l}(2.9$ $\mathrm{mg} / 100 \mathrm{ml}$ ), and alkaline phosphatase $1415 \mathrm{IU} / 1$ (normal $<480 \mathrm{IU} / \mathrm{l}$ ). The low-sodium formula was replaced by a formula containing more calcium and sodium, and a daily dose of $5000 \mathrm{IU}$ of vitamin D2 was begun. Three weeks later there was a pronounced $x$-ray improvement (Fig. 3), serum $\mathrm{Ca}$ was $2.42 \mathrm{mmol} / 1(9.7 \mathrm{mg} / 100 \mathrm{ml})$, inorganic $P$ $1.94 \mathrm{mmol} / 1(6.0 \mathrm{mg} / 100 \mathrm{ml})$, and alkaline phosphatase $716 \mathrm{IU} / 1$. The infant was discharged at 5 months on a standard formula plus a vitamin D2 supplement of $400 \mathrm{IU} /$ day. At 6 months she was well, and her serum $\mathrm{Ca}, \mathrm{P}$, and alkaline phosphatase concentrations were all normal.

Case 2. This 850 -g boy was born at 27 weeks' gestation. Apgar scores were 4 at one minute and 7 at five minutes, and mechanical ventilation was used during the first 55 days of life to treat respiratory distress syndrome. Increased ambient oxygen was required until 90 days of age, and chest $x$-rays confirmed the diagnosis of bronchopulmonary dysplasia.

From day 4 to day 8 of life he received a parenteral amino-acid infusion to supplement his formula feeds (Fig. 2). A daily vitamin preparation (400 $\mathrm{IU} / \mathrm{ml}$ vitamin D2) was ordered but its regular administration could not be confirmed. Oral sodium bicarbonate (1-3 mmol per day) was given as partial treatment for a mild mixed acidosis during the first

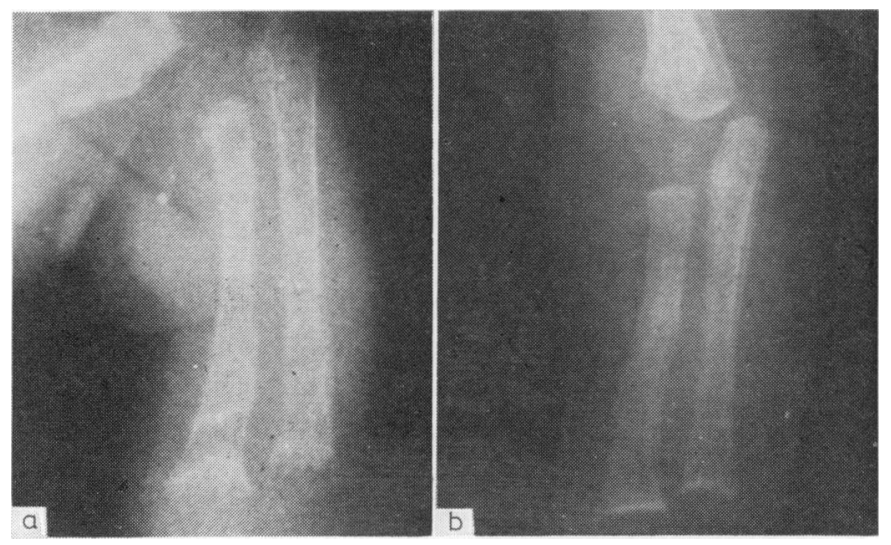

Fig. 3 (Case 1). X-rays of forearm. (a) At age 100 days, showing undermineralisation, metaphyseal flaring, and a pathological fracture of the distal radius. (b) After 3 weeks' treatment of rickets, showing improvement of the rachitic changes. 
8 weeks (Fig. 1). Frusemide (2-3 mg/kg per day, intramuscular or oral) was given during the first 10 weeks for signs of pulmonary oedema (Fig. 1).

On day 105 the diagnosis of rickets was made clinically and by $x$-ray. Serum Ca was $1.85 \mathrm{mmol} / \mathrm{l}$ $(7 \cdot 4 \mathrm{mg} / 100 \mathrm{ml})$, inorganic $\mathrm{P} 1 \cdot 16 \mathrm{mmol} / 1(3 \cdot 6$ $\mathrm{mg} / 100 \mathrm{ml}$ ), and alkaline phosphatase $2128 \mathrm{IU} / \mathrm{l}$. Serum 25-hydroxy-vitamin D3 $\left(25-\mathrm{OHD}_{3}\right)$ was $<16 \cdot 2 \mathrm{mmol} / \mathrm{l}(<6 \mathrm{ng} / \mathrm{ml}$ ) (normal 35-216 mmol/1; $13-80 \mathrm{ng} / \mathrm{ml})$. The infant was treated with $5000 \mathrm{IU}$ vitamin D2 for 3 weeks. Nine weeks later, the $x$-ray and clinical signs of rickets had resolved and serum Ca was $2 \cdot 32 \mathrm{mmol} / 1(9 \cdot 3 \mathrm{mg} / 100 \mathrm{ml})$, inorganic $P$ $2 \cdot 0 \mathrm{mmol} / \mathrm{l}(6 \cdot 2 \mathrm{mg} / 100 \mathrm{ml})$, alkaline phosphatase $801 \mathrm{IU} / \mathrm{l}$, and $25-\mathrm{OHD}_{3}>270 \mathrm{mmol} / \mathrm{l}(>100 \mathrm{ng} / \mathrm{ml})$.

\section{Discussion}

These two patients had rickets diagnosed at 3 to 4 months of age. They each had a birthweight $<1000 \mathrm{~g}$, respiratory difficulties that led to feeding difficulties with a resultant decrease in calcium intake, and an uncertain vitamin D intake; both were treated with sodium bicarbonate, frusemide, and a parenteral amino-acid infusion. All these clinical factors can cause or aggravate rickets. Unlike the patients described by Glasgow and Thomas, ${ }^{4}$ our two infants appear to have had classical bronchopulmonary dysplasia, ${ }^{5}$ which antedated the development of rickets. Both patients had a resolution of their oxygen requirement before the diagnosis and successful treatment of their rickets.

Nutritional vitamin D deficiency was probably important in both patients. Serum $25-\mathrm{OHD}_{3}$ concentrations were measured only in Case 2 who had a low value at an age when a normal serum concentration should be present. ${ }^{6}$ Additionally, a reduced dietary calcium intake could have played a part in causing rickets. Day et al. ${ }^{7}$ demonstrated improved bone mineralisation in infants of very low birthweights when dietary intake of calcium was increased to give the same intake as would have occurred in utero. Kooh et al. ${ }^{8}$ reported a child with isolated dietary calcium deficiency and normal serum 25$\mathrm{OHD}_{3}$ concentration: the patient had clinical, $x$-ray, and biochemical bone disease indistinguishable from vitamin D deficiency rickets, which healed with dietary calcium supplementation alone.

The drugs given to these patients may also have contributed to the development of rickets. Both frusemide and sodium bicarbonate can cause calciuresis in conjunction with natriuresis. Adults treated for hypercalcaemia with normal saline infusions have a pronounced increase in urinary calcium excretion. ${ }^{9}$ Frusemide has been used in the treatment of hypercalcaemia because it increases urinary calcium excretion. ${ }^{10-11}$ Chronic administration of frusemide to neonates has resulted in excessive calciuria, as well as nephrolithiasis and nephrocalcinosis. ${ }^{12}$ Total parenteral nutrition ${ }^{13}$ has also been associated with systemic bone disease in infants of very low birthweights. However, the short duration of this treatment in our patients probably excludes it as a major factor in the development of their bone disease.

A review of the clinical courses of the two rachitic infants thus suggested a number of potentially important aetiological factors including inadequate dietary vitamin $\mathbf{D}$ and calcium intakes, and prolonged treatment with sodium bicarbonate and frusemide. Although the relative contribution of each of these factors cannot be known, this experience stresses the need to guarantee the daily administration of vitamin D supplements and calcium intake to infants of very low birthweights and the need to maintain a high index of suspicion for the occurrence of rickets in such infants receiving prolonged treatment with frusemide or sodium bicarbonate.

\section{References}

1 Eek S, Gabrielsen L H, Halvorsen S. Prematurity and rickets. Pediatrics 1957; 20: 63-77.

2 Lewin P K, Reid M, Reilly B J, Swyer P R, Fraser D. Iatrogenic rickets in low birth weight infants. $J$ Pediatr 1971; 78: 207-10.

3 Tulloch A L. Rickets in the premature. Med J Aust 1974; i: $137-40$.

4 Glasgow J F T, Thomas P S. Rachitic respiratory distress in small preterm infants. Arch Dis Child 1977; 52: 268-73.

5 Northway W H, Jr, Rosan R C, Porter D Y. Pulmonary disease following respirator therapy of hyaline-membrane disease: bronchopulmonary dysplasia. $N$ Engl $\mathrm{J}$ Med 1967; 276: 357-68.

6 Hillman L S, Haddad J G. Perinatal vitamin D metabolism. II. Serial 25-hydroxyvitamin D concentrations in sera of term and premature infants. $J$ Pediatr 1975; 86: 928-35.

7 Day G M, Chance G W, Radde I C, Reilly B J, Park E, Sheepers J. Growth and mineral metabolism in very low birth weight infants. II. Effects of calcium supplementation on growth and divalent cations. Pediatr Res 1975; 9: $568-75$.

8 Kooh S W, Fraser D, Reilly B J, Hamilton J R, Gall D G, Bell L. Rickets due to calcium deficiency. $N$ Engl J Med 1977; 297: 1264-6.

9 Chakmakjian Z H, Bethune J E. Sodium sulfate treatment of hypercalcemia. $N$ Engl J Med 1966; 275 : 862-9.

10 Suki W N, Yium J J, Von Minden M, Saller-Hebert C, Eknoyan G, Martinez-Maldonado $M$. Acute treatment of hypercalcemia with furosemide. N Engl J Med 1970; 283: 836-40.

11 Tambyah J A, Lim M K. Effect of frusemide on calcium excretion. Br Med J 1969; i: 751-2. 
12 Hufnagle K, Penn D, Williams P. Renal calcificationscomplication of long-term high-dose furosemide (abstract). $J$ Pediatr 1978; 93: 314-5.

13 Leape L L, Valaes T. Rickets in low birth weight infants receiving total parenteral nutrition. J Pediatr Surg 1976; $11: 665-74$

14 Forbes G B. Letter: Calcium accumulation by the human fetus. Pediatrics 1976; 57: 976-7.
Correspondence to Dr David R Brown, Department of Pediatrics, Division of Neonatology, MageeWomens Hospital, Forbes Avenue and Halket Street, Pittsburgh, Pennsylvania 15213, USA.

Received 7 August 1979

The following will appear in future issues of this journal:

D-lactic acidosis in a boy with short bowel syndrome. E P Schoorel, $M$ A H Giesberts, W Blom, and $H \mathrm{H}$ van Gelderen

Artificial surfactant therapy for hyaline membrane disease. $J S$ Wigglesworth

Artificial surfactant and natural surfactant. Comparative study of the effects on premature rabbit lungs. Colin Morley, Bengt Robertson, Burkhard Lachmann, Roland Nilsson, Alec Bangham, Gertie Grossmann, and Nigel Miller

Dietary fibre in under- and overnutrition in childhood. D Burkitt, D Morley, and A Walker

Bone marrow transplantation. $A J$ Barrett

Misleading plasma electrolytes in diabetic children with severe hyperlipidaemia. Brian M Frier, Christopher $R$ Steer, Joyce D Baird, and Susan Bloomfield 